\title{
Myeloma: A malignant disorder of bone and soft tissue
}

\author{
Henry J. Mankin, Keith P. Mankin, David C. Harmon \\ 1. Orthopaedic Oncology, Massachusetts General Hospital, Boston, MA, U.S.A. 2. Massachusetts General Orthopaedic \\ Pediatric Service, MA, U.S.A. 3. Clinical and Research Oncology Center, Massachusetts General Hospital, Boston, MA, \\ U.S.A.
}

Correspondence: Henry J. Mankin. Address: 1122A Jackson Building, Massachusetts General Hospital, Boston, MA 02114, U.S.A. Email: hmankin@partners.org

Received: March 6, 2014

DOI : $10.5430 /$ jst.v4n2p36

Online Published: May 16, 2014

Accepted: May 6, 2014

36

\section{Abstract}

The purpose of this brief report is to review a large series of cases of myeloma, a highly malignant tumor. The disease was first described over 150 years ago, but not named myeloma until 1873. The lesion appears to be caused by the production of plasma cells in the bone marrow occasionally associated with amyloid.

Patients present with pain in bones, principally spine, pelvis, ribs, calvarium and long bones. The sedimentation rate is elevated and marrow shows $10 \%$ plasma cells and the sedimentation rate is always elevated. There is no identified genetic cause and the disease is not familial.

The disease has a highly malignant potential. We treated 181 mature adult patients with tumor in multiple sites. $63 \%$ were dead of disease at an average of 4.5 years after diagnosis. The use of some new drugs have been helpful, chiefly lalanlidomide or bortezomib. Radiation appears to be useful for some lesions and bisphosphonates sometimes help support the bone structure.

Despite many efforts over the years and the large number of treatment agents introduced, it is apparent that we do not have sufficient ability or knowledge to control this very troublesome disorder.

\section{Key Words}

Bone or soft tissue myeloma, Poor outcome despite treatment

\section{I ntroduction and history}

Myeloma is a common malignant affliction principally occurring in the bones of mature adults. It was first described by MacIntyre in $1850{ }^{[1]}$ who reported on a patient with episodes of fatigue and bone pain. MacIntyre called the disorder "mollities and fragilitas ossium" ${ }^{[1]}$. Later that year, Henry Bence-Jones tested urine specimens provided by MacIntyre's patients and described the abnormal light chains which later became known as Bence-Jones protein ${ }^{[2]}$. In 1846, Dalrymple described the microscopic features of the disorder ${ }^{[3]}$. Ruzitsky in 1873 introduced the term multiple myeloma ${ }^{[4]}$ and Otto Kahler ${ }^{[5]}$ published an extensive review and at one point, the disorder became known as Kahler's disease. At the turn of the century, the increased serum proteins and rapid sedimentation rate were identified as characteristic and the origin of the tumor was defined as arising from plasma cells ${ }^{[6-10]}$ ( Figure 1). In 1929, the diagnosis was established by bone marrow aspiration and in 1937, the value of immunoelectrophoresis as a diagnostic instrument was introduced ${ }^{[8-10]}$. 
When the disease appears in a single site with few biochemical findings it is known as "solitary plasmacytoma", but many of these became multiple over time ${ }^{[6,8,9,11,12,19]}$. In addition, there are some entities known as monoclonal gammopathies of unknown significance (MGUS) which may or may not be directly related to myeloma ${ }^{[8-10]}$. Another entity that is often included in descriptions of myeloma is Waldenstrom's macroglobulinemia which is a form of myeloid disease associated with plasma cell abnormalities but principally presenting as a bleeding and visceral disorder ${ }^{[8-10,14]}$.

Figure 1. Plasma cells occurring in the lesional tissue (200X)

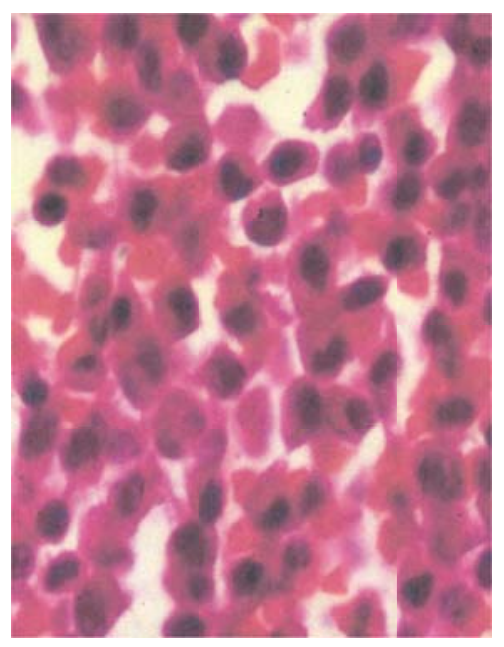

Figure 2. Another characteristic appearance of the plasma cells in the marrow showing some enlarged cells(200X)

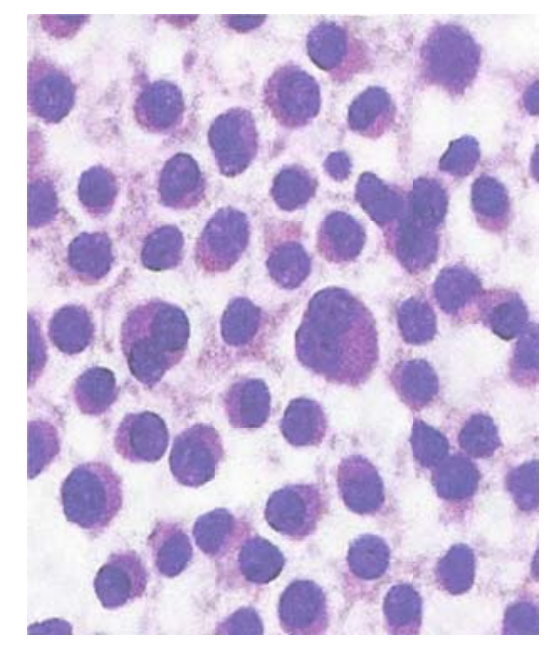

Figure 3. Some of the cells may contain some amyloid which enlarges them and is shown as red in color(200X)

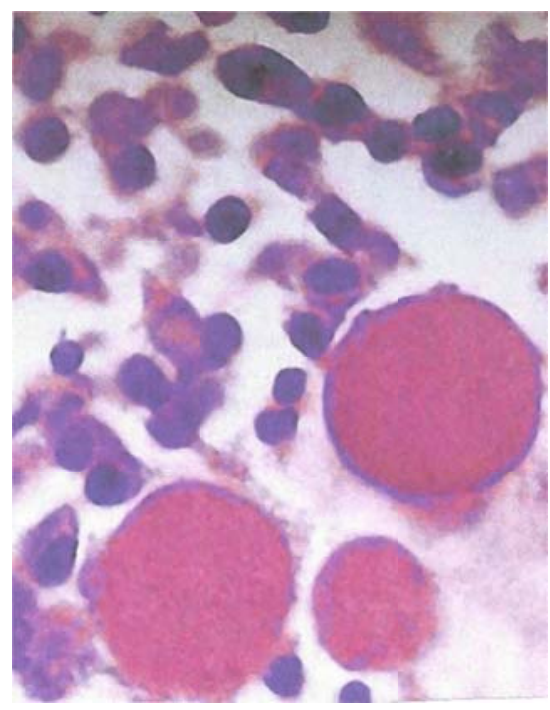


Myeloma occurs principally in older individuals with a mean age of 68 for men and 70 for women ${ }^{[6,9,12,13,15,16]}$. Fewer than $2 \%$ of the patients are under 40 years of age whereas over $50 \%$ are over $70^{[6-9,16]}$. The disease can occur in some animals, principally mice and dogs ${ }^{[9]}$.

\section{Causation and pathogenesis}

The pathogenesis of myeloma is obscure. Increased familial incidence is uncommon, although it is occasionally seen particularly in African-America patients ${ }^{[6-10,15,16,17]}$. Endogenous retrovirus infection has been suggested and initial unsubstantiated report suggested human herpes virus 8 as the cause ${ }^{[6-9,12]}$. Exposure to chemical and physical agents including benzene, petroleum products, pesticides and radiation have all been implicated but none have been clearly established as causative ${ }^{[6,9]}$. Cytogenetic abnormalities are present in at least $60 \%$ of the case and these are often complex with translocations mostly involving chromosome 14q, although 11q, $4 p$ and $8 \mathrm{q}$ have all been identified and implicated ${ }^{[6-8,12,17-19,20-23]}$. Interleukin 6 has been described as being essential to both the growth and maintenance of myelomatous plasma cells and may lead to the production of RANK-L which is known to increase the number of osteoclasts ${ }^{[8,10,24,25]}$. The vascular abnormalities may be related to the production of vascular endothelial growth factor (VEGF) by myeloma plasma cells ${ }^{[8,9,24,26]}$. Despite these findings there is no evidence for a genetic causation and there does not seem to be a familial pattern of transmission.

\section{Clinical presentation of multiple myeloma}

Myeloma can be limited, asymptomatic and insidious ${ }^{[11,27,28]}$, or can be a very severe, disabling and life-threatening disorder ${ }^{[29]}$. In the latter disorder, known as multiple myeloma, production of plasma cells in the bone marrow not only causes weakness of bone structure, pathologic fractures and spinal cord compression, but in addition may result in leucopenia, anemia and thrombocytopenia ${ }^{[6,8,9,10,15,16,28,29]}$ (Figure 1, 2). The cells may contain islands of amyloid (Figure 3). Bence-Jones protein is often present in the urine ${ }^{[6,8,9,12]}$ with corresponding kappa or lambda light chains in the serum. The majority of these patients require extensive treatment but have a relatively poor survival rate. A system for staging was introduced by Durie and Salmon in $1975^{[30]}$ which establishes the various patterns related to the extent of the disease.

\section{Durie-Salmon staging system for multiple myeloma}

\section{Stage I}

Low cell mass: $<0.6 \times 10^{12}$ cells/m² plus all of the following: Hgb $>10$ g/dL, Serum IgG $<5$ g/dL, Serum IgA $<3$ g/dL, normal serum calcium; urine monoclonal protein excretion $<4$ g/day. No generalized lytic bone lesions.

\section{Stage II}

Intermediate cell mass: neither Stage I or Stage III.

\section{Stage III}

High cell mass: $1.2 \times 10^{12}$ cells/m² plus one or more of the following: Hgb <8.5 g/dL; Serum IgG $>7$ g/dL; Serum IgA $>5 \mathrm{~g} / \mathrm{dL}$. Serum calcium $>12 \mathrm{mg} / \mathrm{dL}(3 \mu \mathrm{mol} / \mathrm{L})$. Urine monclonal protein excretion $>12 \mathrm{~g} /$ day. Advanced lytic bone lesions. Stage III is subclassified as IIIA or IIIB based on serum creatinine: IIIA: Serum creatinine $<2 \mathrm{mg} / \mathrm{dl}(177 \mu \mathrm{mol} / \mathrm{L})$. IIIB: Serum creatinine $>2 \mathrm{mg} / \mathrm{dl}$.

Another system has been introduced as the International Staging System (ISS) ${ }^{[31]}$. 
- $\quad$ Stage I $\mathrm{B} 2 \mathrm{M}<3.5 \mathrm{mg} / \mathrm{L}$ and serum albumin $=$ or $>3.5 \mathrm{~g} / \mathrm{dL}$.

- $\quad$ Stage II Neither Stage I or Stage III.

- $\quad$ Stage III $\mathrm{B} 2 \mathrm{M}=$ or $>5.5 \mathrm{mg} / \mathrm{L}$.

Median overall survival for patients with ISS stages I, II and III was 62, 44 and 29 months respectively.

In sharp contrast with the above patterns is the picture of solitary plasmacytoma of bone, which occurs principally in the femoral or axial skeleton ${ }^{[8,9,11,12,15,27,28,33-35]}$ (Figure 4). The bone marrow studies, bone scans and PET-scanning fail to reveal other lesions and immunoelectrophoretic studies and search for Bence-Jones protein fail to support the presence of extensive disease ${ }^{[34]}$. These patients often respond well to radiation alone or excision of the local lesion with surgery $[6,8,9,12,15,27-29,35-38]$.

Figure 4. The myeloid tumor cells may cause destruction of the bone, seen here in the tibia

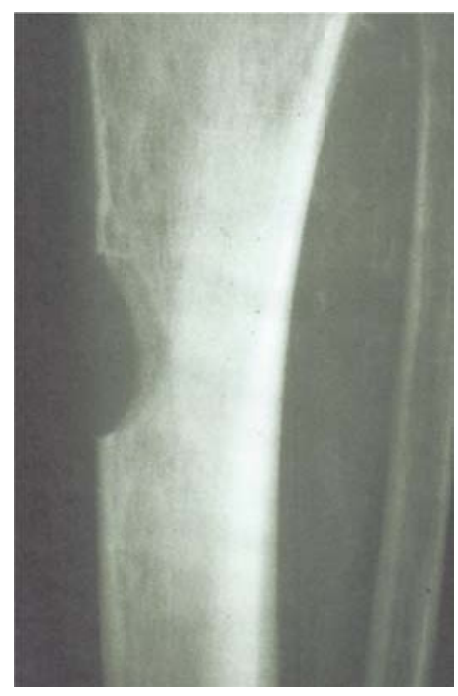

Figure 5. The spine may be involved and show bone destruction and multiple fractures of the vertebrae

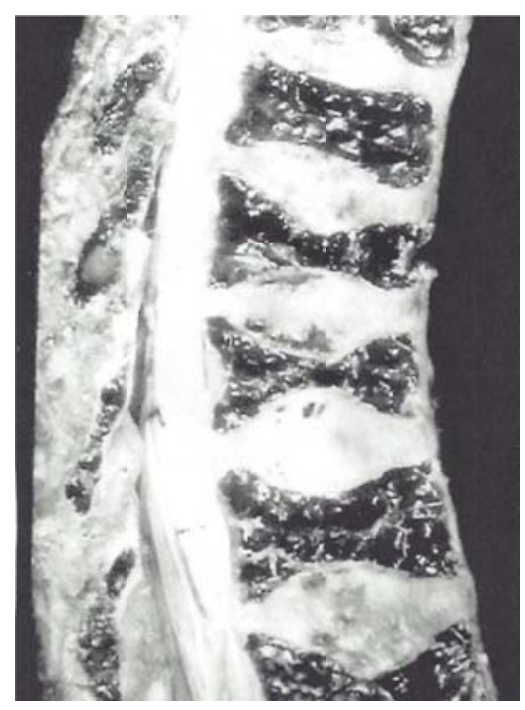

Still another form of the disease which remains a puzzle is monoclonal gammopathy of undetermined significance (MGUS) ${ }^{[6-9,12,32,37,38,40]}$. These patients are found by chance to have an IgG or IgA paraprotein in the serum but no other features to suggest myeloma. These affected patients may have Gaucher disease or Hashimoto's syndrome as well as others ${ }^{[39,40]}$. The bone marrow is normal with fewer than $10 \%$ plasma cells and the patients are asymptomatic. They still 
must be watched and have serial immuno-electrophoretic studies to be certain that the values for the paraproteins do not rise.

Another very rare and puzzling entity associated with myeloma is POEMS syndrome which includes polyneuropathy (P), organomegaly $(\mathrm{O})$, endocrinopathy $(\mathrm{E})$, myeloma $(\mathrm{M})$ and skin changes $(\mathrm{S})^{[9,10]}$. These patients have a very complex presentation but fortunately they seem to respond well to high dose chemotherapy and stem cell transplant ${ }^{[8,9,10]}$.

\section{Clinical studies in patients with multiple myeloma}

Patients with multiple myeloma often present with bone pain associated with a fracture, most often of one or several vertebrae $^{[6,9,10,15,16,29,41]}$ (Figure 5). They may appear chronically ill and many have weight loss, fevers, abdominal distress and neurologic disturbances. Physical examination show bone tenderness in multiple sites including the spine, pelvis, ribs, calvarium and long bones (Figure 6). Laboratory studies show increased amounts of serum IgG or IgA paraproteins on immunoelectrophoresis, Bence-Jones protein in the urine, beta 2 microglobulin (B2M) and kappa or lambda light chains in the serum and a series of abnormalities in blood studies including anemia, leucopenia and thrombocytopenia ${ }^{[6,9,12,15,16,29,41]}$. The sedimentation rate is almost always elevated and the alkaline phosphatase is usually normal or low. Calcium may be greatly elevated and bone marrow studies are likely to show greater than $10 \%$ plasma cells ${ }^{[6,9,12,15,16,41]}$.

Figure 6. A very destructive lesion of the proximal femur which is likely to result in a fracture which is difficult to treat

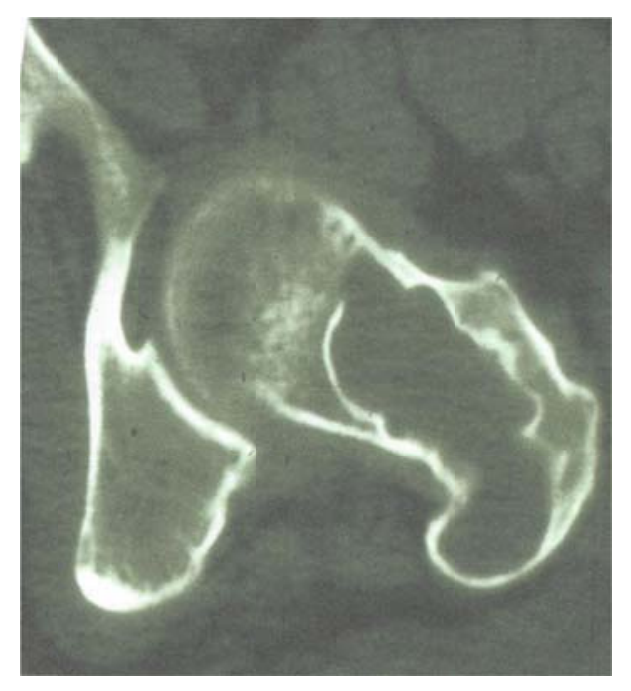

\section{Treatment of multiple myeloma}

There are many forms of treatment for patients with multiple myeloma. Chemotherapy with agents such as vincristine, dexamethasone, bischolorethylnitrosurea, melphalan, cyclophosphamide, prednisone, thalidomide and doxorubicin have all been introduced and are often helpful in reducing the patient's symptomatology and decreasing the extent of the marrow disease $^{[6,9,19,21,37,42-46,48]}$. A recent addition which seems to be quite effective is bortezomib (Velcade) ${ }^{[50]}$. It is frequently used in combination with cyclophosphamide and dexamethasone, or with lenalidomide (Revlimid and dexamethasone). Other combinations include melphalan plus prednisone and thalidomide or lenalidomide plus dexamethasone ${ }^{\text {[46-48] }}$.

Radiation for local lesion is often successful in reducing pain and preventing further fractures ${ }^{[17,21,37,53]}$. Allogeneic marrow transplantation is utilized for severe cases ${ }^{[18,51-53]}$ but in the elderly patients has a high risk of complications. Autologous stem cell transfer is safer particularly for older individuals but includes the risk of re-infusing malignant cells $^{[9,21,33,55,61,62]}$. Orthopaedic management for diffuse disease is principally applied to treatment of fractures, spinal collapses with damage to the cord and destroyed and painful joints ${ }^{[8,9,15,16]}$. Often bisphosphonates in the form of 
pamidronate or zoledronate seem to be helpful in strengthening the bones ${ }^{[57-59]}$ but a recent concern regarding osteonecrosis of the mandible has limited our enthusiasm for the treatment ${ }^{[56]}$. For patients with solitary plasmacytomas, resection or radiation or both have made good success and many patients have become asymptomatic.

\section{Comments, local results and conclusions}

Myeloma is a fairly common neoplasm that can severely affect the patients and in many cause their death.

We have data on 181 patients (Table 1) who presented to our MGH Tumor Service with multiple myeloma treated from 1972 to 2010. The average age was 58 and $63 \%$ of the patients were males. The most prevalent presenting sites were proximal femur, pelvis, lumbosacral spine, proximal arm, shoulder and scapula. 113 patients (63\%) are dead of disease with an average duration of 4.5 years after diagnosis.

Patients treated more recently have a slightly improved median survival. Of 71 patients treated prior to 1995, 48 patients (68\%) died of disease at less than 3 years. Of 36 patients treated from 1995 to 2000, 20 (56\%) died of disease at approximately 4 years. Of the 74 patients treated from 2001 to 2010, 38 (51\%) died of disease with an average survival time of 6 years.

The remarkable feature for multiple myeloma is that despite the fact that the disease was discovered over 100 years ago, we still have no real understanding of the origin of the process, nor of the best possible treatment protocol for these distressed patients. We continue to study the genetics, the clinical nature of the disease and a large number of treatment protocols and let us hope for some improvement in outlook for these patients.

Table 1. Statistics for the series of 181 cases

\begin{tabular}{|c|c|c|c|c|c|}
\hline & & & & Number deceased & $p$-value \\
\hline Total cases seen & \multicolumn{3}{|l|}{181} & 117 (65\%) & \multirow{3}{*}{ N.S. } \\
\hline \multirow[t]{2}{*}{ Gender } & Males & \multicolumn{2}{|l|}{ 116(64\%) } & $74(64 \%)$ & \\
\hline & Females & \multicolumn{2}{|l|}{$65(56 \%)$} & $43(66 \%)$ & \\
\hline \multicolumn{6}{|c|}{ Age : $\quad$ Average age 58 (27-85) } \\
\hline & Ages 27-40 & \multicolumn{2}{|l|}{$18(10 \%)$} & \multicolumn{2}{|l|}{$10(55 \%)$} \\
\hline & Ages 41-60 & \multicolumn{2}{|l|}{$67(37 \%)$} & $41(61 \%)$ & \multirow[b]{2}{*}{$p<.0001$} \\
\hline & Ages 61-85 & 96 (53\%) & & 66 (69\%) & \\
\hline \multicolumn{6}{|l|}{ Anatomic Site } \\
\hline & \multicolumn{3}{|c|}{ Proximal femur 37} & $19(63 \%)$ & N.S. \\
\hline & Pelvis & \multicolumn{2}{|c|}{29} & $20(68 \%)$ & $p<0.001$ \\
\hline & Spine & \multicolumn{2}{|l|}{14} & $10(71 \%)$ & $p<0.0001$ \\
\hline & Humerus & \multicolumn{2}{|l|}{30} & $20(60 \%)$ & N.S \\
\hline & Shoulder & \multicolumn{2}{|l|}{5} & $2(40 \%)$ & $p<0.0001$ \\
\hline & Scapula & \multicolumn{2}{|l|}{16} & $10(62 \%)$ & N.S \\
\hline \multicolumn{6}{|c|}{ Date of Treatment } \\
\hline & \multicolumn{2}{|c|}{ Patients treated prior to 1995} & 71 & 48 (68\%) & \multirow[b]{3}{*}{$p<0.0001$} \\
\hline & \multicolumn{3}{|c|}{ Patients treated from 1995-2000 36} & $20(56 \%)$ & \\
\hline & Patients treated & ed from 2000-2010 & 74 & 38 (51\%) & \\
\hline
\end{tabular}

Note. N.S means not significant 


\section{Acknowledgement}

There are no sources of support that require acknowledgement. The authors have received no funds to support this research publication. All of the figures are from Dr. Mankin's treatment collection or the Dr. Henry Jaffe collection (a famous pathologist who gave his collection of material to Dr. Mankin in 1978).

\section{References}

[1] Alexanian R. Localized and indolent myeloma. Blood. 1980; 56: 521-525. PMid:7407416

[2] Alexanian R, Dimpoulos M: The treatment of multiple myeloma. N Eng J Med. 1994; 36: 1657-1664.

[3] Alyea E, Weller E, Schlossman R et al: T-cell-depleted allogeneic bone marrow transplantation followed by donor lymphocyte infusion in patients with multiple myeloma. Induction of graft-versus-myeloma effect. Blood. 2001; 98: 934-939. PMid:11493435 http://dx.doi.org/10.1182/blood.V98.4.934

[4] Ampil FL, Chin HW. Radiotherapy alone for extradural compression by spinal myeloma. Radiat Med. 1995; 13: 129-131. PMid:7569004

[5] Anderson K. Plasma cell tumors. In Cancer Medicine Edition 5: Bast RC Jr., Kufe DW, Pollock RE, Weichselbaum RR, Holland JE, Frei E III: editors. Hamilton, BC Decker. 2000, 2066-2086.

[6] Badros A, Barlogie B, Siegel E, et al. Autologous stem cell transplantation in elderly multiple myeloma patients over age of 70 years. Br J Haematol. 2001; 114: 600-607. PMid:11552985 http://dx.doi.org/10.1046/j.1365-2141.2001.02976.x

[7] Barlogie B. Zinger M, Spencer T, et al. Thalidomide in the management of multiple myeloma. Semin Hematol. 2001; 38: 250259. http://dx.doi.org/10.1053/shem.2001.26016

[8] Bartl R, Frisch B, Fateh-Moghadam A, et al. Histologic classification and staging of multiple myeloma: a retrospective and prospective study of 674 cases. Am J Clin Pathol. 1987; 87: 342-355. PMid:3825999

[9] Battaille R. Localized plasmacytomas. Clin Haematol. 1982; 11: 113-122.

[10] Bellamy WT. Expression of vascular endothelial growth factor and its receptors in multiple myeloma and other hematopoietic malignancies. Semin Oncol. 2001; 28: 551-559. http://dx.doi.org/10.1016/S0093-7754(01)90023-5

[11] Belluci R, Ayea EP, Weller E et al. Immunologic effects of prophylactic donor lymphocyte infusion after allogeneic marrow transplantation in multiple myeloma. Blood. 2002; 99: 4610-4617. http://dx.doi.org/10.1182/blood.V99.12.4610

[12] Bence Jones H. On a new substance occurring in the urine of patient with mollities ossium. Philo Trans Royal Soc London. 1848; 138: 55-62. http://dx.doi.org/10.1098/rstl.1848.0003

[13] Berenson JR, Lichtenstein A, Porter L, et al. Efficacy of pamidronate in reducing skeletal event in patients with advanced myeloma. Myeloma Aredia Study Group. N Engl J Med. 1996; 33: 488-493. PMid:8559201 http://dx.doi.org/10.1056/NEJM199602223340802

[14] Berenson JR, Rosen LS, Howell A et al. Zolendronic acid reduces skeletal-related events in patients with osteolytic metastases. Cancer. 2001; 91: 1191-1200. http://dx.doi.org/10.1002/1097-0142(20010401)91:7<1191::AID-CNCR1119>3.0.CO;2-0

[15] Bergsagel PL, Kuehl WM. Chromosome translocations in multiple myeloma. Oncogene. 2001; 20: 5611-5622. PMid:11607813 http://dx.doi.org/10.1038/sj.onc.1204641

[16] Bjorkstrand B, Ljungman P, Svensson $\mathrm{H}$ et al. Allogeneic bone marrow transplantation versus autologous stem cell transplantation in multiple myeloma- a retrospective case-matched study from European Group for Blood and Marrow Transplantations (EBMT) Blood. 1996; 88: 4711-4718. PMid:8977265

[17] Callander NS, Roodman GD. Myeloma bone disease. Semin Hematol. 2001; 38: 276-285. http://dx.doi.org/10.1016/S0037-1963(01)90020-4

[18] Campanacci M. Multiple myeloma. In Campanacci M. Bone and Soft Tissue Tumors. 2nd Edition. New York, Springer Verlag. 1999: 581-594. http://dx.doi.org/10.1007/978-3-7091-3846-5_35

[19] Corwin J, Lindberg RD. Solitary plasmacytoma of bone versus extramedullary plasmacytoma and their relationship to multiple myeloma Cancer. 1979; 43: 1007-1013. http://dx.doi.org/10.1002/1097-0142(197903)43:3<1007::AID-CNCR2820430333>3.0.CO;2-4

[20] Dalrymple J. On the microscopical character of mollities ossium. Dublin Q J Med. 1846; 2: 85-95.

[21] Dimopoulos MA, Kastritis E, Anagnostopoulos A et al. Osteonecrosis of the jaw in patients with multiple myeloma treated with bisphophonates: evidence of increased risk after treatment with zoledronic acid. Haematologica. 2006; 91: 968-971.

PMid:16757414

[22] Dimopoulos MA, Moulopoulos LA, Smith T et al: Curability of solitary bone plasmacytoma. J Clin Oncol. 1992; 10: 145-150. 
[23] Durie BGM, Salmon SE. A clinical staging system for multiple myeloma: correlation of measured myeloma cell mass with presenting clinical features, response to treatment and survival. Cancer. 1975; 36: 842-852. http://dx.doi.org/10.1002/1097-0142(197509)36:3<842::AID-CNCR2820360303>3.0.CO;2-U

[24] 24. Epstein J, Xiao HQ, He X-Y. Markers of multiple hematopoietic cell lineages in multiple myeloma. N Engl J Med. 1990; 322: 664-66.

[25] Gahrton G, Svensson H, Cavo M et al. Progress in allogeneic bone marrow and peripheral blood stem cell transplantation for multiple myeloma. Bt J Haematol. 2001; 113: 209-216. http://dx.doi.org/10.1046/j.1365-2141.2001.02726.x

[26] Garcia-Sanz R. Thalidomide in multiple myeloma. Expert Opin Pharmacother. 2006; 7: 195-213. PMid:16433584 http://dx.doi.org/10.1517/14656566.7.2.195

[27] Gerull S, Goerner M, Benner A et al. Long-term outcome of non-myeloablative allogeneic transplantation in patients with high risk multiple myeloma. Bone Marrow Transplant. 2005; 36: 963-969. PMid:16184182 http://dx.doi.org/10.1038/sj.bmt.1705161

[28] Goronov SE, Goanova-Marinova VS. Bortezomib (Velcade)—a new therapeutic strategy for patients with refractory multiple myeloma. Fola Med. 2005; 47: 11-19.

[29] Harada H, Kawano MM, Hujang N et al. Phenotypic difference of normal plasma cells from mature myeloma cells. Blood. 1993; 81: 2658-2663. PMid:8490175

[30] Healy JC, Armstong P. Radiological features of multiple myeloma. In Myeloma: Biology and Management. Malpas JS, Bergsagel DE Kyle RA, Anderson KC editors. Oxford, Oxford University Press. 1998: 235-265.

[31] Hess T, Egerer G, Kasper B et al. Atypical manifestations of multiple myeloma: radiological appearance. Eur J Radiol. 2006; 58: 280-285. PMid:16431064 http://dx.doi.org/10.1016/j.ejrad.2005.11.015

[32] Hussein MA, Oken MM: Multiple myeloma, macroglobulinemia and amyloidosis. In Clinical Hematology and Oncology. Presentation, Diagnosis and Treatment. Furie B, Casileth PA Atkins MB, Mayer RJ editors. Philadelphia, Churchill Livingstone, 2003: 581-600. PMid:12875889

[33] Jantune E, Laakso M: Bisphosphonates in multiple myeloma: current status, future perspectives. Br J Haematol. 1996; 93: 501-506.

[34] Kahler O. Zur symptomoatolgie des multplen myeloma. Beobachtung von albuminurie. Prag Med Wschr. 1889 ; 14 : $33-35$.

[35] Kamble R, Rosenzweig T. Diffuse pulmonary parenchymal involvement in multiple myeloma: antemortem diagnosis. Int J Hematol. 2006; 83: 259-261. PMid:16720559 http://dx.doi.org/10.1532/IJH97.05002

[36] Klein B, Zhang XG, Lu ZY, Bataille R. Inerleukin-6 in human multiple myeloma Blood. 1995; 85: 863-872. PMid:7849308

[37] Knobel D, Zouhair A, Tsang RW et al. Prognostic factors in solitary plasmacytoma of the bone: a multicenter Rare Cancer Network study. BMC Cancer. 2006; 6: 118. PMid:16677383 http://dx.doi.org/10.1186/1471-2407-6-118

[38] Kumar L, Viram P, Kochupillai V. Recent advances in the management of multiple myeloma. Natl Med J India. 2006 ; $19: 80-89$. PMid:16756196

[39] Kuwatsuka Y, Suzuki R, Ichihashi R, Kodra Y. Psuedo-Gaucher cells in light chain plasma cell myeloma. Am J Hematol. 2006; 81: 468-469. PMid:16680751 http://dx.doi.org/10.1002/ajh.20633

[40] Kyle RA. “Benign” monoclonal gammopathy_after 20-35 years of follow-up. Mayo Clin Proc. 1993; 68: 26-36. http://dx.doi.org/10.1016/S0025-6196(12)60015-9

[41] MacIntyre W. Case of mollities and fragilitis osseum accompanied with urine strongly charged with animal matter. Med Chir Trans Lond. 1859; 33:211-232.

[42] Martin MG, Romero Colas MS, Dourdil Sahun MV et al. BaselineTC99-MIBI scanning predicts survival in multiple myeloma and helps to differentiate this disease from monoclonal gammopathy of unknown significance. Haematologica. 2005; 90:1141-1143. PMid:16079119

[43] Matsumoto T, Abe M. Bone destruction in multiple myeloma. Ann NY Acad Sci. 2006; 1068: 319-326. PMid:16831932 http://dx.doi.org/10.1196/annals.1346.035

[44] Munshi NC, Anderson KC. Plasma cell neoplasms. In Cancer Principles and Practices of Oncology 7th Edition. DeVita VT Jr., Hellman S, Rosenberg SA Editors. Philadelphia, Lippincott, William and Wilkins. 2005. pp 2155-2188.

[45] Ogmundsdottir HM, Haraldsdottirm V, Johannesun GM et al. Familiality of benign and malignant paraproteinemias: a population-based cancer-registry study of multiple myeloma families. Haematologica. 2005; 90: 66-71. PMid:15642671

[46] Orchard K, Barrington S, Buscombe J, et al. Fluoro-deoxyglucose positron emission tomography imaging for the detection of occult disease in multiple myeloma. Br J Haematol. 2002; 117: 133-135. PMid:11918544 http://dx.doi.org/10.1046/j.1365-2141.2002.03407.x

[47] Roux S, Meignin V, Quillard J. RANK (receptor activator of nuclear factor-kappa B) and RANKL expression in multiple myeloma. Br J Haematol. 2002; 117: 86-92. PMid:11918537 http://dx.doi.org/10.1046/j.1365-2141.2002.03417.x

[48] Rowell NP, Tobias JS. The role of radiotherapy in the management of multiple myeloma. Blood Rev. 1991; 5: 801-804. 
http://dx.doi.org/10.1016/0268-960X(91)90039-F

[49] Ruzitsky JV. Multiples myelom. Dtsch Z Chir. 1873; 3:162-172. http://dx.doi.org/10.1007/BF02911073

[50] Samson D. Multiple myeloma. In Treatment of Cancer, Fourth Edition. Price P, Sikora K, editors. London Arnold Publishers; 2002: 997-1016.

[51] Schajowicz F. Tumors and Tumorlike Lesions of Bone and Joints. New York, Springer- Verlag; 1981: 281-302. http://dx.doi.org/10.1007/978-1-4684-0098-4

[52] Shaugnessy J, Tian E, Sawyer J et al. High incidence of chromosome 13 deletion in multiple myeloma detected by mutiprobe intephase FISH. Blood. 2000; 96: 1505-1511.

[53] Speer SS, Semenza JC, Kurfosaki T, Anton-Culver H. Risk factors for acute myeloid leukaemia and multiple myeloma: a combination of GIS and case-control studies. J Environ Health. 2002; 64: 9-16. PMid:11901667

[54] Tosi P, Gamberi B, Giuliani N. Biology and treatment of multiple myeloma. 2006; 12: 81-86.

[55] Tosi P, Zamagni E, Cellini C et al. First line therapy with thalidomide, dexamethasone and zolendronic acid decrease bone resorption markers in patients with multiple myeloma. Eur J Haematol. 2006; 76: 399-404.

PMid:16480429 http://dx.doi.org/10.1111/j.0902-4441.2005.t01-1-EJH2520.x

[56] Van Camp B, Durie BG, Spier C et al. Plasma cells in multiple myeloma express natural killer cell-associated antigen CD56 (NKH-1:Leu-19). Blood. 1990; 76:377-382. PMid:1695113

[57] Vesole D, Simic A, Lazarus HM. Controversy in multiple myeloma transplants: tandem autotransplants and mini-allografts Bone Marrow Transplant. 2001; 28: 725-735. PMid:11781623 http://dx.doi.org/10.1038/sj.bmt.1703254

[58] Waldenström J. Incipient myelomatosis or “essential” hyperglobulinemia with fibrogenopenia-a new syndrome? Acta Med Scand. 1944; 117: 216-247. http://dx.doi.org/10.1111/j.0954-6820.1944.tb03955.x

[59] Zandecki M. Multiple myeloma. Almost all patients are cytogenetically abnormal. Br J Haematol. 1996; 94:217-217. http://dx.doi.org/10.1046/j.1365-2141.1996.d01-2939.x 